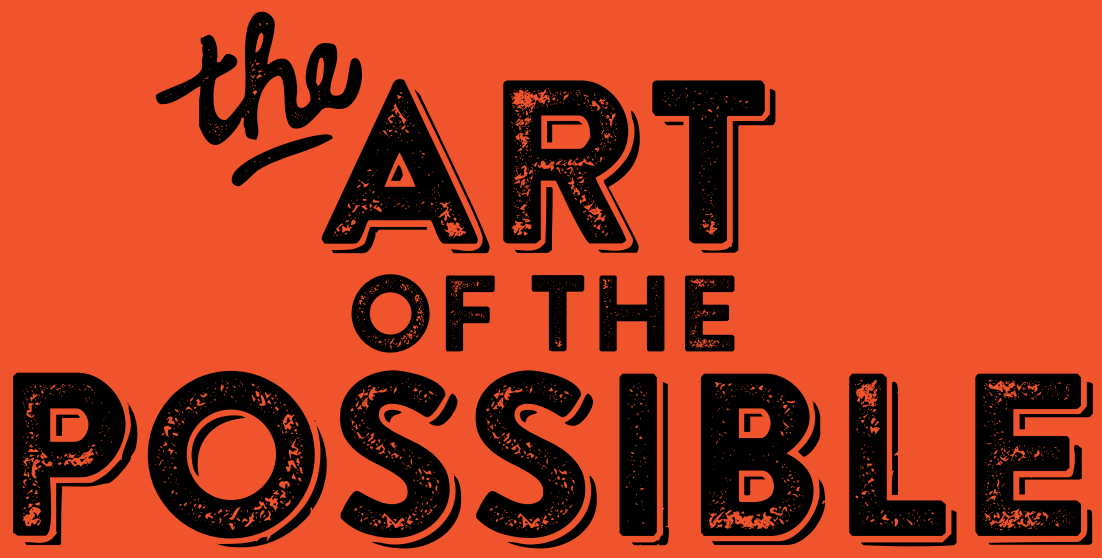

POLITICS AND GOVERNANCE IN MODERN BRITISH HISTORY, 1885-1997:

ESSAYS IN MEMORY OF DUNCAN TANNER

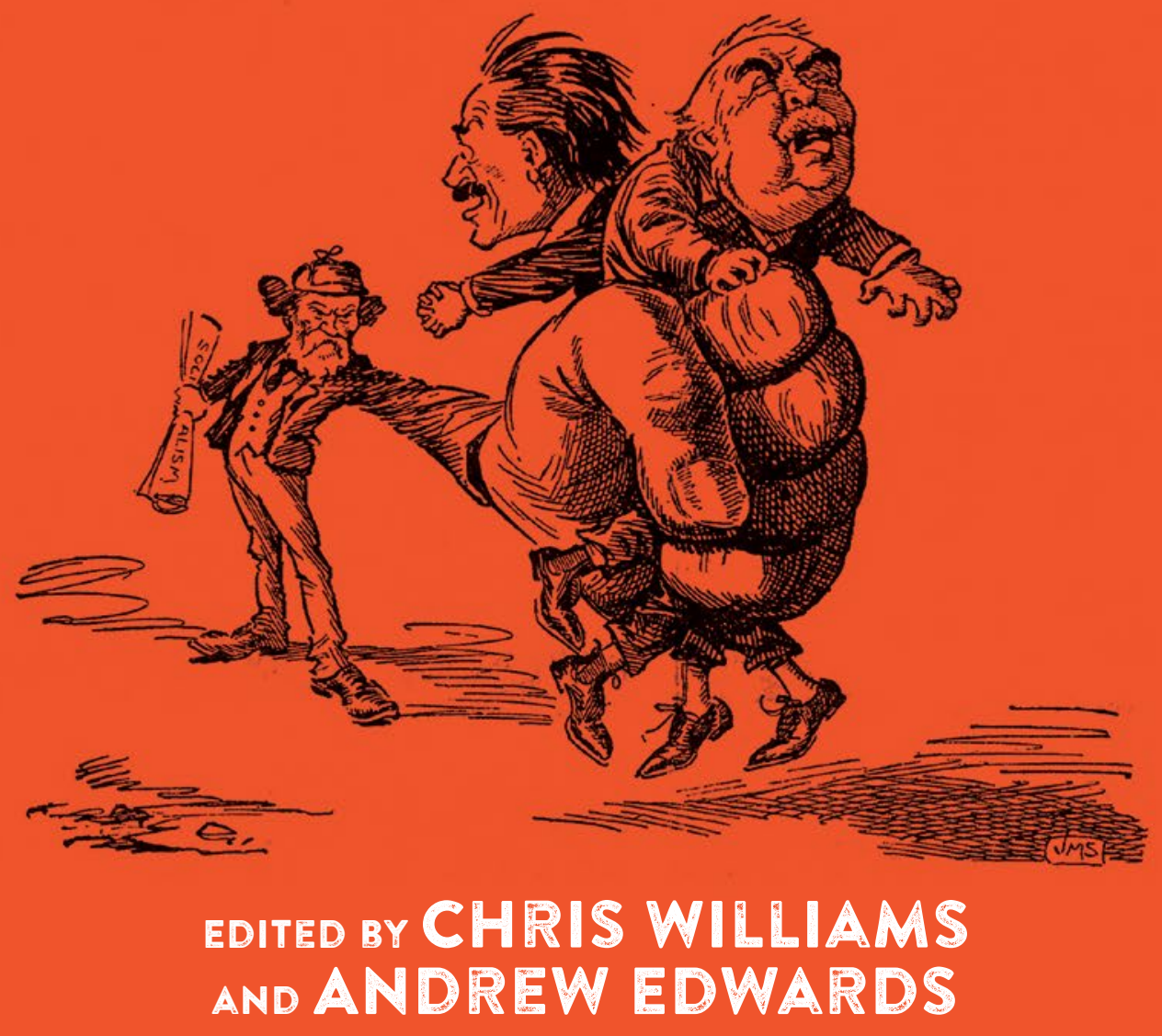


Chris Williams and Andrew Edwards - 9781784991562 Downloaded from manchesterhive.com at $04 / 26 / 2023$ 10:06:42AM 


\section{The art of the possible}

$\overline{\overline{2}}$

\section{MANCHESTER 1824}

Manchester University Press 
Chris Williams and Andrew Edwards - 9781784991562 Downloaded from manchesterhive.com at $04 / 26 / 2023$ 10:06:42AM 


\title{
The art of the possible
}

\begin{abstract}
Politics and governance in modern British history, 1885-1997: essays in memory of Duncan Tanner
\end{abstract}

Edited by

Chris Williams and Andrew Edwards

Manchester University Press 


\section{Copyright (C) Manchester University Press 2015}

While copyright in the volume as a whole is vested in Manchester University Press, copyright in individual chapters belongs to their respective authors, and no chapter may be reproduced wholly or in part without the express permission in writing of both author and publisher.

Published by Manchester University Press

Altrincham Street, Manchester M1 7JA

www.manchesteruniversitypress.co.uk

British Library Cataloguing-in-Publication Data

A catalogue record for this book is available from the British Library

Library of Congress Cataloging-in-Publication Data applied for

ISBN 9780719090714 hardback

First published 2015

The publisher has no responsibility for the persistence or accuracy of URLs for any external or third-party internet websites referred to in this book, and does not guarantee that any content on such websites is, or will remain, accurate or appropriate.

Typeset by

Servis Filmsetting Ltd, Stockport, Cheshire

Printed in Great Britain by

CPI Antony Rowe Ltd, Chippenham, Wiltshire 